\title{
Expression of cytokine-mRNA in PBMC of HIV-1 subtype $C$ infected individuals with opportunistic viral infections from South India
}

\author{
Jaiprasath Sachithanandham ${ }^{*}$, Veena Vadhini Ramalingam¹, Jaganathan Raja', Ooriyapadickal Cherian Abraham², \\ Susanne A Pulimood ${ }^{3}$, Rajesh Kannangai ${ }^{1}$
}

From 2nd International Science Symposium on HIV and Infectious Diseases (HIV SCIENCE 2014)

Chennai, India. 30 January - 1 February 2014

\section{Background}

HIV disease progression is associated with marked change in the level of plasma cytokines. The study reported here investigated the level of mRNA expression of different cytokines: TNF alpha, INF-gamma, IL-10 and IL-21 in the peripheral blood mononuclear cells (PBMC) among the HIV infected individuals with viral opportunistic infections.

\section{Methods}

We quantified the mRNA levels of 4 cytokines in PBMC directly from the blood of individuals infected with HIV and normal healthy controls using TaqMan based RealTime PCR.

\section{Results}

The mRNA expressions of all the 4 cytokines in HIV-1 infected individuals were significantly higher compared to healthy controls ( $p$ value range 0.0004-0.01). The mean level of IL-10, INF-gamma and TNF alpha were higher in HIV infected individuals with low CD4 counts $(<300$ cells/ $\mu \mathrm{L})$. The IL-10 expression showed a significant negative correlation with CD4 counts $(r=-0.25$, $p=0.04)$ while IL-21 showed a positive correlation with CD4 counts $(r=0.26, p=0.03)$. There was significant negative correlation between the CMV viral load and IL-21 expression.

\section{Conclusion}

The study showed a significant negative correlation between CD4+ T cell counts and IL-10 mRNA expression

\footnotetext{
* Correspondence: jaiprasath@gmail.com

'Departments of Clinical Virology, Christian Medical College, Vellore, India Full list of author information is available at the end of the article
}

showing a shift towards $\mathrm{TH} 2$ profile during the late stages of the HIV disease in subtype $\mathrm{C}$ infected individuals. This study on HIV-1 subtype $C$ infected individuals with opportunistic viral infections like EBV and CMV adding new information in such specific opportunistic infections.

\section{Authors' details}

'Departments of Clinical Virology, Christian Medical College, Vellore, India. ${ }^{2}$ Internal Medicine, Christian Medical College, Vellore, India. ${ }^{3}$ Dermatology, Christian Medical College, Vellore, India.

Published: 27 May 2014

\section{doi:10.1186/1471-2334-14-S3-E10}

Cite this article as: Sachithanandham et al: Expression of cytokinemRNA in PBMC of HIV-1 subtype $C$ infected individuals with

opportunistic viral infections from South India. BMC Infectious Diseases 2014 14(Suppl 3):E10.

Submit your next manuscript to BioMed Central and take full advantage of:

- Convenient online submission

- Thorough peer review

- No space constraints or color figure charges

- Immediate publication on acceptance

- Inclusion in PubMed, CAS, Scopus and Google Scholar

- Research which is freely available for redistribution

Submit your manuscript at www.biomedcentral.com/submit
() Biomed Central 